\title{
Development of Learning Devices Using Model Problem Based Learning to Improve Problem Solving Abilities Senior High School
}

\author{
Merti Sanni P. Marbun \\ Graduation Mathematics Education Post \\ Universitas Negeri Medan \\ Medan, Indonesia \\ sannimerti@gmail.com
}

\author{
Pargaulan Siagian \\ Mathematics Education \\ Universitas Negeri Medan \\ Medan, Indonesia
}

\author{
Abil Mansyur \\ Mathematics Education \\ Universitas Negeri Medan \\ Medan, Indonesia
}

\begin{abstract}
This study aims to: Describe the learning device with the model problem based learning that meets the criteria of valid, practical, and effective; Describe the improvement of problem solving abilities by using learning tools with the model problem based learning developed. This research is a development research conducted in two stages. Learning tools generated from this study are: Learning Implementation Plans, Student Activity Sheets, Teacher Books, Student Books, test problem solving abilities. From the results of the first trial and trial II, it was obtained: the learning device with the model problem based learning developed has met the criteria of valid, practical, and effective in terms of each criteria; there is an improvement in students' mathematical problem solving abilities classically by using learning tools with the model problem based learning developed in the first trial and the second trial was $23.34 \%$.
\end{abstract}

Keywords-Problem solving ability, 4-D model, Learning device development with model problem based learning.

\section{INTRODUCTION}

Human knowledge of mathematics has an important role in human civilization, so mathematics is a field of study that is always taught at every level of education in schools. Remembering that mathematics plays a very important role in human survival so that many experts and practitioners of mathematics education always try to develop students' knowledge of mathematics. As expressed by Cockcroft "it would be very difficult - perhaps impossible - to live a normal life is very much a part of the world" [1]. It would be very difficult or impossible for someone to live in this part of the earth in the 20th century without using the least of mathematics.

The National Council of Teachers of Mathematics (NCTM) states that there are abilities that students must achieve in learning mathematics, namely: " School mathematics standards include content standards (mathematical content) and process standards (mathematical processes). The standard covers the process of problem solving, reasoning and proof, connections, communication, and representation. The standard of the process is jointly the basic skills and understanding needed by students in the $21 \mathrm{st}$ century“. [2]
These skills are high order mathematical thinking important for students to develop in the process of learning mathematics. One of the mathematical abilities that need to be developed is the ability to solve problems.

Problem-solving ability is the ability of students to solve mathematical problems by paying attention to the process of finding answers based on the steps of problem solving (understanding the problem; planning problem solving; solving problems; and checking again) that was presented by Polya [3]. Problem solving is seen as a process to determine the combination of a number of rules that can be applied in an effort to overcome a new situation. Problem solving skills are very important for students and their future. Learning experts agree that the ability to solve problems within

Learning devices are a set of learning resources that are arranged in such a way that students and teachers conduct learning activities, tests to measure learning outcomes and so on [4]. Learning tools are very important for a teacher, because: (1) Learning tools provide guidance on what a teacher must do in the classroom. Provide guidance in developing teaching techniques, (2) Learning devices as benchmarks, namely a professional teacher must evaluate the learning tools. This is important to improve the professionalism of a teacher, (3) Learning tools as an enhancement of professionalism, namely the professionalism of a teacher can be improved by means of learning means that learning devices are not only as administrative completeness, but as a medium for increasing professionalism, a teacher must develop and use the device learning so that the activities of the teaching and learning process can succeed.

Of the cases in the field, the low ability of problem solving and understanding of students' concepts is caused by several factors including: first, the unavailability of learning tools that are in accordance with the expectations above. Conditions in the field of students only use textbooks and student activity sheets that are published / circulated by certain institutions. This shows that teachers rarely make their own teaching materials such as student activity sheets. As we know the existing student activity sheets does not reflect the appropriate student activity sheets. student activity sheets usually only requires regular exercises without developing students' problem solving skills and understanding concepts as 
expected. Second In addition to text books and student activity sheets, the test instruments provided by the teacher are also inadequate. based on information obtained from the teacher that so far the test instruments provided by the teacher have not directed students to solve problems. The test given so far is only in the form of questions that refer to mere knowledge. The questions given by the teacher are often taken from the questions in the student package. This is not as expected: students are able to solve problem solving ability test questions. So it needs to be ignored by developing a test that is capable of telling students to solve problems. Third, the learning implementation plans made by the teacher also does not contain a model, a method that can activate students in the learning process.

Development of learning tools must be arranged based on the right learning model as well. The use of learning models that are not in accordance with the development of students will have an impact on the development stage of student learning. Istarani states that: "The learning model is a whole series of presentation of teaching materials that cover all aspects before the medium and after learning done by the teacher and all related facilities that are used directly or indirectly in the teaching and learning process" [5]. With these characteristics, it is expected that the learning model will be expected to increase student learning outcomes.

To achieve the above objectives, there needs to be a learning model that can overcome the educational problems that have been previously revealed. An effective and good learning model to be used in the process of learning mathematics is quite a lot. However, if you want to develop mathematical learning that is contextual, one of the learning models that can be used is the model Problem Based learning. Problem Based learning can be applied to the learning of mathematics to improve students 'problem solving abilities and understanding of students' concepts. According to "Problem-based learning is learning that exposes students to practical problems as a foundation in learning or in other words students learn through problems"[6]. This learning helps students to process information that has been formed in their minds and compile their own knowledge about the social world and its surroundings.

The reason why choosing PBL models is to improve mathematical problem solving because PBL is constructivist where students focus more on developing thinking skills and problem solving skills, as well as skills in communication and collaboration and arranging understanding concepts that students have in conducting investigations, and social skills that require reflection from various perspectives. Students are also asked to make the most of their expertise in their group members. The role of the teacher is as a facilitator and provides assistance to students.

From the description of the above problems, researchers are interested in conducting research related to the mathematical abilities of students and their relation to the existence of mathematics learning devices. So the researchers are interested in researching about the Development of Learning Tools Using Problem Based Learning Models to
Improve the Mathematical Problem Solving Ability of Senior High School

\section{RESEARCH METHOD}

This study included research development pemebelajaran device that refers to the 4-D models Thiagarajan, which consists of four stages, namely the definition phase define, design, develop, disseminate .Learning tools are developed using models problem based learning namely Learning Implementation Plans, Student Activity Sheets, Teacher Books, Student Books, and problem solving ability tests. Model development in this study schematically shown in Figure 1.

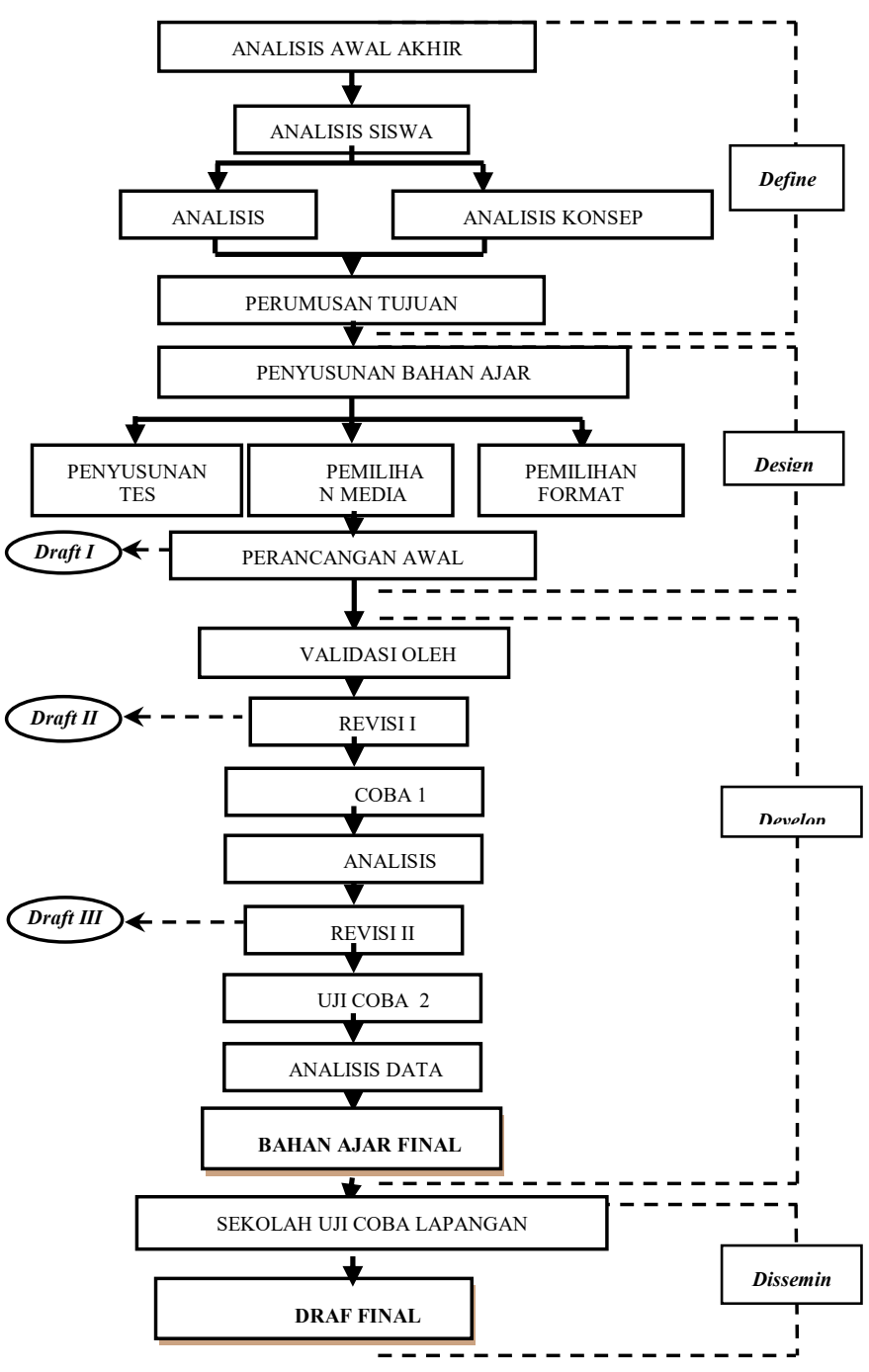

Fig 1. Modification Chart Development of teaching materials Thiagarajan Model 4-D

Description:

$\underset{\text { Activity Results }}{\longrightarrow}$ Process Activity

\section{A. Stage of Defefition (Difine)}

This stage aims to determine and define the requirements needed for developing learning. 
Determination of the required conditions is done by paying attention to and adjusting learning needs by analyzing the objectives and limitations of the material for students. The activities carried out in the defining stage are front end analysis (final initial analysis), student analysis, concept analysis, task analysis, and specification of learning objectives.

\section{a) Initial and Final Analysis}

Analysis The final preliminary analysis activity aims to raise and determine the basic problems encountered in learning mathematics at Senior high school so that the development of learning tools is needed. Based on this problem an alternative development of relevant learning tools was developed. At this stage the study of the mathematics curriculum used, the basic problem analysis of the teacher and students, and the learning theories that underlie the PBL model so that a description of the learning pattern is considered ideal.

Based on the results of observations conducted at Senior High School that the curriculum used is the 2013 curriculum. Then an analysis of the learning devices Senior High School shows that all this time the teacher does not have a good learning device. Then the handbook used does not contain questions that contain problem solving. In addition, in the learning process students are not involved in the process of finding knowledge but are directly given by the teacher. This is thought to be the cause of low problem solving abilities.

Based on the description above, it seems that there is a problem in the process of learning mathematics in Senior High School To overcome this problem it is necessary to develop learning tools using the model PBL in solving the problems given. Thus, it is expected that problem solving abilities will increase.

\section{b) Student Analysis}

At this stage, students' characteristics are analyzed according to the design and development of learning tools. Characteristics of students studied include cognitive development, academic ability and socio-economic background of students. According to Piaget's cognitive development, children aged 11 years to adulthood have achieved formal operational development. At this stage the child has been able to think abstractly and is able to solve problems, this is in accordance with the use of PBL-oriented learning tools.

\section{c) Concept Analysis}

At this stage, identification of the basic concepts of statistical material is carried out. Concept analysis relates to the analysis of the material to be studied by students, namely by making concept maps that will facilitate students in understanding the subject matter

\section{d) Analysis of Task}

Analysis is carried out to identify the stages of completion of tasks performed by students during learning which refers to concept analysis, in addition to the details of task analysis for statistic material on Core Competencies and Basic Competencies.

\section{e) Formulation of Learning Objective}

formulation of learning objectives is a reference in designing teaching materials. The formulation of learning objectives is carried out to describe indicators of achievement of learning outcomes to be more specific indicators that are adjusted based on the results of material analysis and analysis of tasks that have been done previously.

\section{B. Stage Design (Design)}

The purpose of this stage is to prepare a prototype learning tools for model-based statistical material Problem Based Learning.This stage starts after a specific learning is set. This stage includes the preparation of tests, selection of media, selection of formats and initial design.

\section{a) Preparation of test}

Basicpreparation is an analysis of tasks and concepts outlined in the specification of learning objectives. The test in question is a test of statistical problem solving ability. To design the test, a question grid is made based on the indicator of problem solving ability, based on the indicator of the ability of problem solving ability and the scoring reference.

\section{b) Media Selection}

Selection is adjusted to the results of the task analysis, concept analysis and characteristics of students of SMAN 1 Andam Dewi, because media is useful to help students in achieving Basic Competencies. The selection of media is done to determine the right media in the presentation of learning material and adapted to the characteristics of students and the facilities contained in the school.

\section{c) Selection of Format}

Selection of formats in developing this learning tool is intended to design learning tools, selection of strategies, approaches, learning methods, and learning resources. The format chosen is a format that meets the criteria of interest, facilitates and assists in statistical learning. The choice of format or form of presentation of learning is adjusted to the learning media that will be applied.

\section{d) Preliminary Design}

Activities carried out in this step are the initial drafting of statistical learning tools which include the teacher's manual, student books, as well as student activity sheets, learning implementation plans, tests of problem solving skills. The initial design is referred to as draft 1 .

\section{Stage of Development}

The development stage is the stage to produce the product development carried out by two steps, namely: (1) 
expertappraisal followed by a revision, (2) developmental testing.

This phase includes draft II, namely: revising teaching materials that have been reviewed by experts / experts, then teaching materials that have been revised and are good according to experts, then tested and analyzed. Furthermore, in draft III, namely: the data that has been analyzed is revised again, then proceed to trial II and re-analyzed.

\section{Deployment Phase}

Development of the final stages of the learning device if it has obtain a positive assessment of experts and through test development. Learning devices are then packaged, distributed, and set for a wider scale. In this study the dissemination stage was limited, namely in the experimental class. If after testing the results are very good and effective, it needs to be considered as a learning device solution that can be used in the classroom. However, for widespread distribution it is left to the next party.

\section{RESULT AND DISCUSSION}

Based on the formulation of the problems and research questions submitted in the previous section, based on the data obtained from the results of trials 1 and 2 it will be known whether the problem formulation and the proposed research questions have been answered or not. The results of data analysis obtained from the results of trials 1 and 2 show: (1) learning devices with models problem based learning developed valid; (2) learning tools with themodel problem based learning developed practically; (3) learning tools with the model problem based learning developed effectively; (4) there is an increase in problem solving ability by using learning tools with the model problem based learning developed;

\section{The validity of Model Learning Tools Problem Based Learning developed}

Based on the results of the validation of the learning device with the model of the PBL that was developed, it was found that the learning tools with models were problem based learning, Learning Implementation Plans, Teacher Books, Student Books, and Student Activity Sheets . valid or have a good degree of validity. Furthermore, the results of the validation of the test of problem solving ability are also valid or have a good degree of validity. This shows the device of learning through the model problem based learning developed both Learning Implementation Plans, Teacher Books, Student Books, and Student Activity Sheets, tests of problem solving skills students have fulfilled the validity criteria.

Validity criteria were obtained through the assessment of experts on learning devices with the model problem based learning developed. The availability of valid learning devices is caused by several factors, including: first, the learning device with the model problem based learning developed has fulfilled the content validity. This means that in the development of learning tools with the model is in problem based learning accordance with the demands of the existing curriculum. The curriculum demands are related to core competencies and basic competencies that must be achieved by students in learning activities that are tailored to the material or content of the learning provided and adjusted to the steps of the learning device with the model problem based learning.

The learning device with the model problem based learning developed has fulfilled the construct validity. That is, in the development of learning tools with models problem based learning are in accordance with the concepts and indicators of problem solving ability and understanding of mathematical concepts which are further combined with the model problem based learning (adjusted to the characteristics and principles of the model problem based learning). The learning tools developed are compiled complementary between Learning Implementation Plans, Teacher Books, Student Books and Student Activity Sheets which are adapted to the model problem based learning to measure problem solving abilities. Fulfillment of good aspects of validity as stated above, in line with the opinion of Rohman \& Amri which states that, the aspect of validity refers to the extent to which the design of the device developed is based on content validity and construct validity. [7]

Based on the results of the research and opinions above, and supported by development research conducted by Rusmono [8], which is based on the results of the development of learning tools that have been carried out have met valid criteria. Valid is illustrated from the results of the validator's assessment that all validators state both content (according to curriculum), construct (according to the characteristics / principles of learning) and language (in accordance with the applicable language rules, namely improved spelling).

\section{Praticality of Learning Tools with the Model Problem Based Learning Developed}

The results of the practicality assessment of the learning tools were obtained from the expert / practitioner assessment stating that the learning tools developed could be used with little revision or without revision. Based on the results of expert assessments, the components of learning tools developed in the form of Learning Implementation Plans, Teacher Books, Student Books, Student Activity Sheets, problem solving ability tests is practical / can be used with minor revisions.

Practicality is that the learning tools that are prepared consider the ease. Ease in the sense that the learning tools that are arranged are easy to understand and also easy to implement or use [9]

Then according, "Another characteristic of high-quality interventions is that end-users (for instance the learners and learners) consider it easy to use to use the materials in a way that is largely compatible with the developers' intentions. If these conditions are met, we call these interventions practical" [9], which means that other criteria of quality learning tools are users (teachers and students) can easily use the material in 
a way that is very suitable for the intent of the developer (who develops learning tools )

For practicality assessment, then from the observations of the feasibility of learning devices in the class included in the high category $(3 \leq K G<4)$ or very high $(4 \leq K G \leq 5)$ and the instrument is said to be good if it has a reliability coefficient $\geq 0.75$ or $\geq 75 \%$. This second aspect of practicality assessment is explained as follows.

Practical criteria that are reviewed from the feasibility of the learning tools in this study, have also met the practical criteria. In the first trial and trial II, the implementation of the learning tool had fulfilled the established criteria, namely achieving a very high category of $(4 \leq K G \leq 5)$ and for the reliability of learning instruments with the model problem based learning in trial I and trial II had also reached the specified category, namely the instrument can be said to be good because it has reached the reliability coefficient $\geq 0.75$ or $\geq 75 \%$. Indeed in the first trial, some students were still unfamiliar with the use of learning devices with models problem based learning that demanded student activities, but in subsequent trials students became more accustomed and happy.

Practical learning tools are obtained due to several things. As for some things that support practicality are: (1) Learning Implementation Plans that are prepared are easy to understand and easy to use by teachers and students in the learning process; (2) The steps with the model are PBL easily implemented by the teacher; (3) Student Activity Sheet which is prepared is easily understood by students because the instructions given are clear, the writing is easy to read, and the pictures and tables used are easy to understand and interesting; (4) Teacher Books and Student Books which are arranged in easy-to-understand sentences and learning materials are presented systematically; and (5) the sentence of the questions and statements on the test of problem solving abilities is not ambiguous (has more than one meaning) and the workmanship commands are easy to understand.

Based on the description above, it can be concluded that the learning tools developed with the model problem based learning have fulfilled practicality as expected. Thus the learning device through the model problem based learning is developed easily and can be implemented by teachers and students.

\section{Effectiveness of Learning Tools with Model Problem Based Learning Based developed}

On the results of the first trial and trial II, the device with the model problem based learning developed has fulfilled the effective category in terms of: (1) classical student learning completeness; (2) students give a positive response to the learning device components with the model problem based learning developed and 3) the teacher's ability to manage learning in a good category. The aspects of each of the effective categories above are explained as follows.

\section{Classical Student Learning Completeness}

Based on the results of the analysis posttest of trial I and trial II, it was found that problem solving skills and understanding of mathematical concepts of students had met classical completeness criteria, where there was an increase in classical learning completeness in problem solving abilities of $23.34 \%$ and at $30 \%$ concept comprehension ability. This is because the material and problems in the student book and activity sheet are developed in accordance with the conditions of the student learning environment and refers to the learning device through the model problem based learning. With the application of learning tools through the model problem based learning, students will be actively involved in the problem solving process. Students analyze and evaluate their own thought processes and make conclusions from the knowledge that has been found with the guidance and guidance of the teacher or friend in the form of questions that lead.

This is also supported by the results of Saragih and Habeahan's research showing that "In the PBL the student is given that the LAS contains contextual issues close to students so that students are able to develop creativity and problemsolving abilities. In PBL students can increase again. " [10] Meaningful in PBL students given Student Activity Sheets contain contextual problems close to the state of students so that students are able to develop creativity and problem solving abilities. The PBL model is also accustomed to students discussing with their friends in solving problems so that students' problem solving abilities and creativity can be improved again.

Based on the results of research and support of previous research above, it can be seen that learning devices with the model PBL developed can help students achieve classical learning completeness. Thus it can be concluded that, the use of learning devices with the model PBL developed has met the effective criteria.

\section{Student Response}

Based on the results of the analysis of the results of trial I and trial II, it was found that the average percentage of student responses in each trial was positive. This means that students provide a positive response to the components of the learning device with the model PBL developed. Student responses given to each trial have reached the predetermined criteria category, namely $\geq 80 \%$. This shows that, the learning device with the model PBL developed has met the effective criteria in terms of student responses.

In line with the results of the above studies, problem-based learning is based on the premise that problematic situations that are confusing or unclear will arouse students' curiosity and make them interested in investigating. In other words, the learning device through the model PBL can arouse students' interest in learning so that learning activities become effective.

According to Daryanto learning is a process of change that is a business process that is carried out by a person to obtain a new behavior change as a whole as a result of interaction with the environment [11]. This is because the learning process is complex, where students determine whether they will learn or not. In line with Vigotsky's theory, namely: "zone of proximal development; namely learning occurs when the child works or learns to handle tasks that have not been studied but the tasks 
are still in their abilities or the tasks are in the zone of poximal development; and (2) scaffolding that is giving large amounts of aid to a child during the early stages of learning, then the child is taking over greater responsibility as soon as he can do it himself. [12]

Thus, the actions / responses made by students on the stimulus in the form of teaching as an activity can be categorized into two things, namely a positive response to learning (listening, reading, writing, discussing / asking) or a negative response (other actions that are not relevant). A positive response indicates that students are willing to follow the learning process.

Furthermore, the positive response given by students is caused because the teacher has provided a stimulus in the form of feedback and reinforcement that is appropriate to the characteristics of students after learning the state of the class. In other words the teacher is a very decisive component in implementing a learning strategy. A teacher must prepare a mature and accurate learning planning process because with the learning planning the teacher will be able to predict how much success will be achieved.

Based on the exposure of the research results and supporting research, it can be concluded that the components of the learning device with the model PBL developed contribute positively to the students' responses to learning.

\section{The Ability Of The Teacher To Manage Learning}

The last criterion of effectiveness in terms of the ability of teachers to manage learning has met the effective criteria. In the first trial and trial II the ability of teachers to manage learning has fulfilled good categories $3,50 \leq \mathrm{KG} \leq 4,50$.

Based on the results of data analysis the results of the trial I obtained the average value of the teacher's ability to manage learning is 3.84 in the good category and the trial II obtained an average value of 4.122 where in the criteria the ability of teachers to manage the learning set in chapter III, then the average value is in the good category $3.50 \leq \mathrm{KG} \leq 4.50$.

From the research of Amalia, Surya and Syahputra (2017) which shows that "A teacher's teaching and learning strategies influence educational outcomes. Observations suggest that pupils from schools as well as teachers prefer Whose problems in case the algorithm suitable for Reviews their solution is apparent, in Whose case there are no doubts about the choice of the suitable algorithms" [13]. Meaningful the attitude of a teacher and the teaching strategies used will significantly affect the results of students' abilities. Observations from schools indicate that students and teachers prefer learning that is preceded by problems in the learning process for solutions to solutions.

Improving Problem Solving Ability Using Learning Tools with the Model Problem Based Learning developed

One of the goals obtained from the development of learning tools with the model PBL in This research is to improve students' mathematical problem solving abilities. Using the PBL model, the role of the teacher becomes very important, namely being a facilitator, the teacher must be able to direct or help students to determine what is known, what is needed to know and where they can find important information, so that students are able to understand what and why they have to study. The learning process using the model PBL has a positive impact on the development of problem solving abilities and helps students develop intellectual discipline and skills needs to arouse curiosity and seek answers to their curiosity.

The results of research from Eviyanti, Surya, Syahputra, and Simbolon show that "Theoretically the problem-based learning has several advantages that problem based learning students in learning engages models activities so knowledge really absorbed properly, these models make students actively solve problems and require thinking skills students are higher than students can experience the benefits of learning mathematics because the problems are solved daily life problems. " [14] meaningful Theoretically problem based learning has several advantages namely problem based learning model involving students in learning activities so that students' knowledge really absorbed well, this model makes students actively solve problems and demand higher thinking skills so students can experience the benefits of learning mathematics.

In this study, the level of mastery of students in terms of problem-solving ability by using tests of problem solving abilities that have been developed. Based on Table 1, shows that the average student problem solving ability at the results pretest is 66.667 and posttest is 74.833 . Description result in the problem solving ability test I are shown in Table 1.

TABLE 1. Description Results Problem Solving Ability Test

\begin{tabular}{|c|c|c|}
\hline \multirow{2}{*}{ Description } & \multicolumn{2}{|c|}{ Problem Solving Ability } \\
\cline { 2 - 3 } & Pretest & Posttest \\
\hline Top Value & 80 & 90 \\
\hline Lowest Value & 45 & 60 \\
\hline Average & 66.667 & 74.833 \\
\hline
\end{tabular}

classical completeness of the results of solving abilities the problem of students in pretest trial I was $43.33 \%$ while the classical completeness of students' problem solving ability in the first posttest trial was $63.33 \%$. In accordance with the criteria of completeness of student learning outcomes classically, that is at least $75 \%$ of students who take the test of problem solving ability can achieve a score of $\geq 75$. Thus, the results of posttest problem solving abilities have not met classical completeness because they only get a percentage of $63.33 \%$ completeness. So it can be concluded that in the trial I the application of learning devices with the model PBL developed did not meet the criteria for achieving classical completeness. Description result in the problem solving ability test I are shown in Table 2. 
TABLE 2. The level of completeness Classical Problem Solving Ability Trial I

\begin{tabular}{|c|c|c|c|c|}
\hline \multirow[b]{2}{*}{ Category } & pretest & \multirow{2}{*}{$\begin{array}{c}\text { Percentage } \\
\text { Complete } \\
\text { Classical } \\
\end{array}$} & \multirow{2}{*}{$\begin{array}{c}\text { Posttest } \\
\text { Number of } \\
\text { Students }\end{array}$} & \multirow{2}{*}{$\begin{array}{r}\text { Percentage } \\
\text { Complete } \\
\text { Classical }\end{array}$} \\
\hline & $\begin{array}{c}\text { Number of } \\
\text { Students }\end{array}$ & & & \\
\hline Completed & 13 & $43.33 \%$ & 19 & $63.33 \%$ \\
\hline $\begin{array}{c}\text { Not } \\
\text { Completed }\end{array}$ & 17 & $56.67 \%$ & 11 & $36.67 \%$ \\
\hline Total & 30 & $100 \%$ & 30 & $100 \%$ \\
\hline
\end{tabular}

The average problem solving ability of students in the trial II results of the pretest was 70.5 and the posttest was 85.16 If categorized based on the level of mastery students, then the mastery level of problem solving ability on the results of pretest and posttest trial II can be seen in Table 3.

TABLE 3 Description of Results II

\begin{tabular}{|c|c|c|}
\hline \multirow{2}{*}{ Description } & Problem Solving Capability Problem Solving Ability \\
\cline { 2 - 3 } & Pretest Posttest & Testability \\
\hline Top Rated & 80 & 95 \\
\hline Lowest Value & 55 & 70 \\
\hline Average & 70,5 & 85.16 \\
\hline
\end{tabular}

Classical completeness of the results of students' problemsolving abilities on the pretest II trials by $53.33 \%$ while the classical completeness ability the problem solving of students in the posttest trial II was $86.67 \%$. In accordance with the criteria of completeness of student learning outcomes classically, that is at least $75 \%$ of students who take the test of problem solving ability are able to achieve a score of $\geq 75$. Thus, the results of posttest problem solving abilities meet completeness in a classical manner because they obtain a percentage of $86.67 \%$ completeness. So it can be concluded that in the Trial II the application of learning devices with the model PBL developed has met the criteria for achieving classical completeness. For more details can be seen in Table 4 below.

TABLE 4. Level Complete Classical Problem Solving Ability Trial II

\begin{tabular}{|c|c|c|c|c|}
\hline \multirow{2}{*}{ Category } & pretest & \multirow{2}{*}{$\begin{array}{l}\text { Percentage } \\
\text { Complete }\end{array}$} & posttest & \multirow{2}{*}{$\begin{array}{l}\text { Percentage } \\
\text { Complete } \\
\text { Classical }\end{array}$} \\
\cline { 2 - 4 } & $\begin{array}{c}\text { Number of } \\
\text { Students }\end{array}$ & Classical & $\begin{array}{c}\text { Number of } \\
\text { Students }\end{array}$ & \\
\hline Completed & 16 & $53.33 \%$ & 26 & $86.67 \%$ \\
\hline $\begin{array}{c}\text { No } \\
\text { Completed }\end{array}$ & 14 & $46.67 \%$ & 4 & $13.33 \%$ \\
\hline Total & 30 & $100 \%$ & 30 & $100 \%$ \\
\hline
\end{tabular}

From the explanation above the classical completeness of students' problem solving ability in posttest trial I was $63.33 \%$ and classical completeness in posttest trial II was $86.67 \%$ so that it can be concluded that classical completeness mastery of problem solving abilities from trial I and trial II $23.34 \%$. Based on the exposure and data analysis of the above problem solving abilities, it is known that the development of learning devices with models PBL encourages students to be able to understand the problems that have been learned and those in their thinking to build a knowledge acquired.

\section{CONCLUSION}

Based on the results of the analysis and discussion in this study, it can be concluded as follows: The

A. Validity of the developed learning device is included in the valid category with the average total value of Learning Implementation Plans, validity of 4.56, the teacher's book of 4.56 , the student's book of 4.53 , Student Activity Sheets is 4.50 , test items of problem solving ability of students have also been in the valid category.

B. Learning tools developed with the model PBL have met practical criteria in terms of: (1) expert / practitioner assessment states that the learning device with the model of PBL developed can be used with a slight revision; and (2) the feasibility of learning devices has reached a high category, namely in the first trial of 3.67 and in the second trial of 4.02 .

C. Learning tools developed with the model PBL have met the effective criteria. Effective criteria in terms of: (1) classical student learning completeness has been achieved $86.67 \%$ and $86.67 \%$ in trial II; (2) the ability of teachers to manage pursuit increased from the first trial of 3.84 to 4.122 in the second trial in the good category; and (3) positive student response to the components of learning devices and learning activities developed.

D. The improvement of students' mathematical problem solving ability using learning tools with the model PBL in statistical material was $23.34 \%$, in the posttest trial I classical completeness was $63.33 \%$ and the second trial was $86.67 \%$.

\section{Acknowledgment}

In this occasion the author expressed his appreciation and profound gratitude to Mr. Hisar Marbun and Mrs. Linsahni Tumanggor who have supported the author in terms of morale and meteril. The author also expresses my deepest gratitude to all parties who have helped until this paper can be completed.

\section{References}

[1] Shadiq, F. 2014.Pembelajaran Matematika Cara Meningkatkan Kemampuan Berfikir Siswa, Penerbit Graha Ilmu, Yogyakarta

[2] Hasratuddin. 2015. Mengapa harus belajar matematika?. Medan: Perdana Publishing

[3] Nurdalilah. 2013. Pengembangan Perangkat Pembelajaran Berorientasi Konstraktivisme untuk Mengajarkan Konsep Perbandingan Trigonometri Siswa Kelas X SMA. Jurnal Pendidikan Matematika. 3 (2): 57-72

[4] Latief, M. 2009. Penelitian Pengembangan. Malang: Universitas Negeri Malang

[5] Istarani. 2012. Model Pembelajaran Inovatif. Medan: Media Persada

[6] Wena, Made. 2009. Strategi pembelajaran Inovatif Kontemporer: Suatu Tujuan Konseptual Operasional. Jakarta: Bumi Aksara

[7] Rohman and Amri 2013. Desain Model Pengembangan Perangkat Pembelajaran. Jurnal Kreano, (Online), Vol. 3 No.1,Juni 2012, ISSN:20862334,http://journal.unnes.ac.id/nju/index.php/kreano/article/vi ew/2613/2672

[8] Rusmono. 2012. Model-Model pembelajaran Mengembangkan Profesionalisme Guru Edisi Dua. Jakarta: PT Raja Grafindo Persada

[9] Nieveen, N. 2007. An Introduction to Education Design Research.China: The east China Normal University.

[10]Saragih and Habeahan. 2014. The Improving of Problem Solving Ability and Students' Creativity Mathematical by Using Problem Based Learning 
in SMP Negeri 2 Siantar. Journal of Education and Practice www.iiste.org ISSN 2222-1735 (Paper) ISSN 2222-288X (Online) Vol.5, No.35.

[11]Daryanto. 2013. Inovasi pembelajaran Efektif. Bandung: Yrama Widya.

[12]Trianto, 2011. Mendesain Model Pembelajaran Inovatif-Progresif: Konsep, Landasan dan Implementasinya pada Kurikulum Tingkat Satuan Pendidikan (KTSP). Jakarta: Kencana.

[13]Amalia, Surya and Syahputra. 2017. The Effectiveness Of Using Problem Based Learning (Pbl) In Mathematics Problem Solving Ability For Junior
High School Students. Vol-3 Issue-2 IJARIIE-ISSN(O)-2395-4396: https://www.researchgate.net/publication/318663630

[14]Eviyanti, Surya, Syahputra and Simbolon. 2017. Improving the Students Mathematical Problem Solving Ability by Applying Problem Based Learning Model in VII Grade at SMPN 1 Banda Aceh Indonesia. ISSN 2394-9686 International Journal of Novel Research in Education and Learning Vol. 4, Issue 2, Available at: www.noveltyjournals.com 